\title{
Evaluation of Concept Maps Related To Angle Concept Created By Fifth Grade Students
}

\author{
Güler TULUK ${ }^{1}$
}

\begin{abstract}
The purpose of this study is to investigate the effects of teaching by concept maps of the angle concept, one of the basic concepts in the curriculum of 5 th grade geometry course and measurement sub-area, on students' learning performance. At a secondary school in a central district of the western Black Sea region, one of two classes was randomly chosen as the experimental group, and the other as the control group. In the experimental group, the students were taught angle concept using concept maps Inspiration9 package. The students in the control group were taught using traditional method(simple lecturing) . In teaching angle concept, teaching using concept maps significantly affected performance and attitude towards math of the students taught using concept maps, compared to the group taught using traditional method. Concept maps with active learning strategy can induce different discoveries in math lessons without being bound by a single evaluation and help students establish links between the concepts.
\end{abstract}

Keywords: Angle concept, teaching geometry, 5th grade students

\section{INTRODUCTION}

Today, visual literacy (data - information - concepts - Strategy - metaphor components (http://www.visual-literacy.org/periodic_table/periodic_table.html) is an important component in the development of metacognitive strategies. Grouping and classifying skills are acquired in this way. Concept maps, which represent classification of knowledge to acquire and visual presentation of the link between knowledges through keywords, facilitate meaningful learning of new information based on existing knowledge of the students and support problem solving and critical thinking skills (Demirel, 2002; Baki, 2008, Burak, 2010).

The concept maps suggested for the first time by Novak and his students in 1974 are based on Ausubel's theory, in which the learners organize concepts, their cognitive structures in a hierarchical manner from general to specific in meaningful learning (Novak and Gowin, 1984). Arrangement and implementation of teaching activities in an organized manner by taking into account the structures of the subjects facilitate students to perceive and accordingly understand. Concept maps are used as hierarchical-stage maps (Novak and Gowin, 1984); spider maps (Jones et al., 1987; Harnisch et al., 1994) and linear chains.

\section{Teaching the Angle Concept}

The dictionary of science and art terms of the Turkish Language Association defines "concept" as follows:

1. A general idea of something involving many different perceptions about it.

2. A mental image of any event, any quality, or any quantity.

3. An abstract thought that gains meaning when its scope and content are explained through a symbol or a word.

In educational sciences, a concept is

"A general design that covers the common features of objects or events and collects them under a common name; the projected combination of interrelated qualifications or attributes (properties) in a single word that determines the essence of a single object (individual concept) or class of objects (general concept)".

\footnotetext{
1 Yrd. Doç. Dr., Kastamonu Üniversitesi, Eğitim Fakültesi, gtuluk@kastamonu.edu.tr
} 
Object concepts are concepts that state the essence and the founding characteristics of an object based on ideas. Object concepts may be individual and focus on a single object (i.e. Kizilirmak). Then, they are called "individual concepts". When these concepts address the common features of an object group, they are referred to as "species concepts" (i.e. stream, brook, river). "Species concepts" with common features establish a "genus concept". Each genus concept may also be the species concept of an upper genus concept, which continues until the last genus concept at the top of the concept pyramid. This pyramid is a system of concepts. In this system, there is a continuous rise to an upper and more general genus concept. The system of concepts reaches its peak in the last genus concept. Through division (Lat. divisio), a way is made inversely for lower genera and species. In the end, indivisible individuals are reached (http://tdk.gov.tr/index.php?option=com_bilimsanat\&view=bilimsanat\&kategoriget=terim \&kelimeget=kavram\&hngget $=\mathrm{md}$ ).

As quoted by Dede (2003) from Toumasis, the following steps should be taken into consideration in the teaching of a concept:

1. The definition of the concept should be at the center of teaching,

2. The critical features of the concept should be known,

3. The relationships between the concept and its related sub-concepts and metaconcepts as well as the dimension of such relationships should be determined.

Length and angle are the two basic concepts of geometry. Angle is interpreted in different ways depending on where it is defined in the educational process. For example, it is also used in the slope of the road. There are researchers who think that the activities related to angle concept should be started during preschool period and in primary school (Clements and Battista, 1990).

\section{Background of the Study}

Configuration of human knowledge is discussed within cultural and historical processes. Researchers summarize that development of an individual (ontogeny) is related to development of a race (phylogeny) (Aktr. Keiser, 2009). Ontogeny is intellectual development in an individual's mind, while phylogeny is intellectual development within cultural and historical processes. Similarly, Sinclair (1991) argues that children try to gain this knowledge acquired by mankind over thousands of years in a short-term math course or within other scientific disciplines, which we call learning or teaching.

In intellectual development of an individual, concept image suggested by Tall and Vinner (1981) can be considered. They represent concept image as total cognitive structure which contains all the mental pictures and associated properties and processes. In this respect, image is defined as: 1 . the thing designed and realized by a person in his mind, although it is not related to reality. 2. The form revived in the mind of a former sensory perceptual without any clear stimulus. (http://tdk.gov.tr/index.php?option=com_bilimsanat\&view=bilimsanat\&kategoriget=terim \&kelimeget=imge\&hngget=md ). In short, image which can be defined as the picture in the mind evokes visual image at first glance. Images are needed to think. And images contain thoughts. Visual images in mind are generated in order to comprehend the world of mathematics.

According to information processing theory, human cognition or learning focuses on how human memory system acquires, converts, stores information, generates, retrieves and uses codes. Psychologists are of the opinion that visual and verbal coding of information highly contributes to recalling. In this respect, value of early experience in geometry is important (Fuys, 1988; Noss, 1987). Students begin to study these angle models resulting from informal physical conditions in 3rd grade. First preliminary knowledge is created. They begin to see an angle inside a shape (Piaget and Inhelder, 1956) in primary school at fourth 
and fifth grades. Therefore, teachers perform various activities for younger students to better understand representations of angle concept and different states of angles, and their differences in a certain state.

Point, which does not make sense alone and is undefined in the curriculum, is associated with ray concept and thus, angle concept is revealed. In books, the expression "angle is the combination of two rays sharing a common starting point on a plane" is used. $A O B=B O A=[O A U[O B$. Point $\mathrm{O}$ which is initially undefined form the corner/starting point of an angle, while rays $[O A$ ile $[O B$ form the sides of the angle and acquire meaning as the angle (http://w3.gazi.edu.tr/ gtuluk/trigo_web/aciyay.htm, http://acilar-acilar.blogspot.com/2012/06/21-ac-ve-temel-kavramlar.html).

Angles are formed under a wide range of physical conditions between which it is not easy to ensure conformance (Freudenthal 1983; Mitchelmore, 1995, 2000). For example, the same angle can be measured on the slope of a hill, on a doorknob, on opening of a pair of scissors or the rise of the sun in the sky, however, all of these situations are very different experiences in different contexts.

Mitchelmore and colleagues break down angle situations into three clusters; scissors),

- 2 line angles (corners of room or a geometric inset, intersecting roads, pairs of

- 1 line angles (doors, windshield wipers),

- 0 line angles (the turning of a doorknob or a wheel).

In this way, they draw attention to the configuration using turns, slopes, crossings , bends, rebounds, corners while addressing angles in daily life. In geometry coursebooks of 1960s in Turkey, angle concept is also addressed in this way based on Euclidean Geometry (Çizenel,1967; Gökmen, 1967; Erdem, 1968).

Mitchelmore (2000) identifies three stages of knowledge about angles:

- Situated angle knowledge. Knowledge of specific situations where angles are observed by the child, for example, a steep hill or the corner of a geometric inset.

- Contextual angle knowledge. More general knowledge that integrates related situations, for example, slope of hill with slope of roof, or turn of a doorknob with turn of a jar lid.

- Abstract angle knowledge. More general knowledge that integrates different angle contexts, for example slopes and turns.

Clements (1990) considers the development of the geometric understanding as something that occurs in stages. He modifies van Hiele's stages and proposes levels;

- precognition (Level 0),

- Level 1 (visual); at this level children might say that they recognize a rectangle because it looks like a door),

- Level 2 (descriptive/analytic); at this level, learners recognize a shape by its attributes, for example, a square has four equal sides and four right angles),

- Level 3 (abstractional/relational); children can categorize objects hierarchically by attributes, for example they see that a square is a rhombus with the extra constraint of having four right angles),

- Level 4 (this last level is the level at which learners can construct proofs).

The concept of angle is used differently for different physical conditions (Freudenthal, 1983; Mitchelmore, 1995, 2000). Keiser (2004) highlights three points in regard to the concept of angle:

What exactly is being measured when referring to the size of angles?

Can angles contain curves?

Why are $0^{\circ}, 180^{\circ}$, and $360^{\circ}$ angles difficult to conceive? 
The concept of angle is used differently for different physical conditions (Freudenthal, 1983; Mitchelmore, 1995, 2000). Keiser (2004) highlights three points in regard to the concept of angle:

1. What exactly is being measured when referring to the size of angles?

2. Can angles contain curves?

3. Why are $0^{\circ}, 180^{\circ}$, and $360^{\circ}$ angles difficult to conceive

\section{Technology in Teaching Concept Maps}

Many software programs are used to create computer-assisted concept maps (http://en.wikipedia.org/wiki/List_of_concept-_and_mind-mapping_software). In this way, grouping for concepts, classification, critical properties, their correlations with upper and lower concepts are revealed, while strategies of recalling, which we call retrieving, are begun to be developed. Children aged 11 or 12 gain repeat strategies, while recalling strategies may also accompany this.

As from 3rd grade, conductive cognitive strategies may also begin to develop. In this way, meaningful learning of new knowledge is ensured based on students' existing knowledge; their problem solving and critical thinking skills can be supported. As from 3rd grade, conductive cognitive strategies may also begin to develop. In this way, meaningful learning of new knowledge is ensured based on students' existing knowledge; their problem solving and critical thinking skills can be supported (Baki, 2008).

The present study employed the Inspiration software (http://www.inspiration.com/), which is an appropriate tool for brainstorming, planning, organizing, drafting, preliminary preparation, delineation, creating concept maps, and transition to a web environment. The software is free for use for 4 weeks after it is downloaded from the web. The Inspiration software provides many conveniences for beginners, small children, and specialized users for improving their creativity in addition to forming concept maps (Baki \& Şahin, 2004). Due to the library included in the software, different pictures and figures may be used for concepts and ideas. In addition, users may create their own libraries or add their own pictures. One of the most attention-grabbing features of the software is its appearance in the form of a concept map and a mind map. When requested, the concepts included in the concept map can be presented like a diagram, and the relationships between such concepts may be displayed as an ordered concept list. Conversely, listed concepts may be converted into a diagram. Another easy-to-use feature is that explanatory notes may be added to each figure or symbol included in the diagram when needed, and they may be displayed in the form of a list.

Learning areas of computer-aided concept maps:

- Free Configuration: This area requires students to be able to evaluate the results and have appropriate implications for feedback. Students configure their own concept maps only with the help of feedback.

- Segment Configuration: Students possess concept maps with concepts or links placed in some blanks as feedback.

- Reminder: Some blanks (concepts or links) are left in the system while filling in concept maps. Students freely put their answers on their concept maps (Chang vd, 2001).

- Defining: Some blanks are left in the system (concepts or links). The system shows concepts and links which can be placed in the blanks of the concept map. Students choose their answers from the concepts and links given (Tsai vd, 2001).

\section{Attitude}

Attitude is a tendency attributed to an individual, which creates his thoughts, feelings and behaviors related to a psychological object on a regular basis, with underlying diuturnity and cognitive, affective and behavioral forms. Attitude affects behavior along with 
environmental factors, rather than doing so on its own and directly (http://w2.anadolu. edu.tr/aos/kitap/ EHSM/1024/unite12.pdf).

An assessment tool used to determine individuals' opinions, thoughts on or attitudes toward a subject (e.g. students' opinions, thoughts on or attitudes toward math course) is called an attitude scale. One of the most important goals of mathematics education is to develop a positive attitude towards mathematics (Reyes, 1984). This goal is also included in Turkey Ministry of Education's Curriculum for Elementary Mathematics Course.

The attitude scale used in the research was developed by Nazlı Çiçek and Erktin (2002). This attitude scale is a 5 point Likert -type scale with 20 items stating positive and negative judgments, and its alpha reliability coefficient was found as 0.74 as a result of scale development studies.

\section{Purpose of the Research}

The research was conducted on randomly chosen 2 classes, with one being the experimental group and the other being the control group, in a secondary school of Ministry of National Education, situated in a city centre of Western Black Sea region. In the experimental group, angle concept was taught using concept maps by inspiration 9 package, while in the control group, traditional teaching method using conventional instructional technologies (blackboard-notebooks-pencils) was applied.

There are various studies that measured cognitive structures and conceptual understanding (Baki\&Şahin, 2004; Aktaş \& Güler, 2011; Burak, 2010, Güçlüer, 2006, Henderson, 1994, Kabaca, 2003; Özdemir, 2009).

Cognitive psychologists agree on the similarity of the internal representation of knowledge to webpages or networks that are connected to one another just like organized and well-established spider webs (Hiebert \& Carpenter, 1992; Hiebert \& Lefevre, 1986; Pintrich, Marx, \& Boyle, 1993; Royer, Cisero, \& Carlo, 1993). While creating this network, cognitive strategies are used, outlined, classified, created in mind, and symbolized. When an individual executes pieces of information belonging to a particular area, s/he runs these pieces of information in an interrelated and configured manner among a large pile. Concept methods introduce useful and interesting teaching into class so using them as a teaching method and assessment tool should be made a common practice (Şahin, 2002: 17).

Atasoy (2002) argued that concept maps show how students see a subject. Therefore, teaching angle concept was conducted using activities studying the details.

\section{Problem}

A variable is called an object, property or state that takes various and different values from observation to observation (Kaptan, 1998). The dependent variable of this study is student performance measured by the Mathematics Performance Test, and the independent variable, the cognitive support delivered by concept maps.

“Are $5^{\text {th }}$ grade students' academic performances and attitudes toward math influenced by teaching approach based on concept maps and traditional teaching method in teaching angle concept during selective math course for $5^{\text {th }}$ grades in elementary school?"

Sub-problems directing this research are as follows:

1. Is there a significant difference between final test scores of the experimental and the control groups?

2. Is there a significant difference between final attitude scores of the experimental and the control groups? 


\section{METHOD}

In the study, an experimental design with a pretest and a posttest control group showing repeatable measurements (pretest - posttest) was used. The sample of the research was comprised of $5^{\text {th }}$ grade students taking math course in 2 classes at a secondary school in a central district of a city in Western Black Sea region during the academic year 2013-2014.

Table 1

\begin{tabular}{cccc} 
School & group & sample & TOTAL \\
\hline \multirow{2}{*}{ Middle school 5. Grade } & Experiemental Group & 27 & 48
\end{tabular}

Teacher of the control group stated that she delivered the subject of "Angles" to students by verbal narration and the students noted down what she wrote on the blackboard. She also told that she asked questions related to the subject to students during the lesson and finished the lesson by solving exercise questions so as to intensify the subject.

Functioning: After the pretest, the researchers, as the course teacher, moved onto the implementation stage for the experimental group in line with their previously developed lesson plans. Before the implementation, the experimental group was given information about concept maps and a concept map initially consisting of parts in which such parts were brought together according to the gains of 5 th grade math course related to number concept was created (Figure 1).

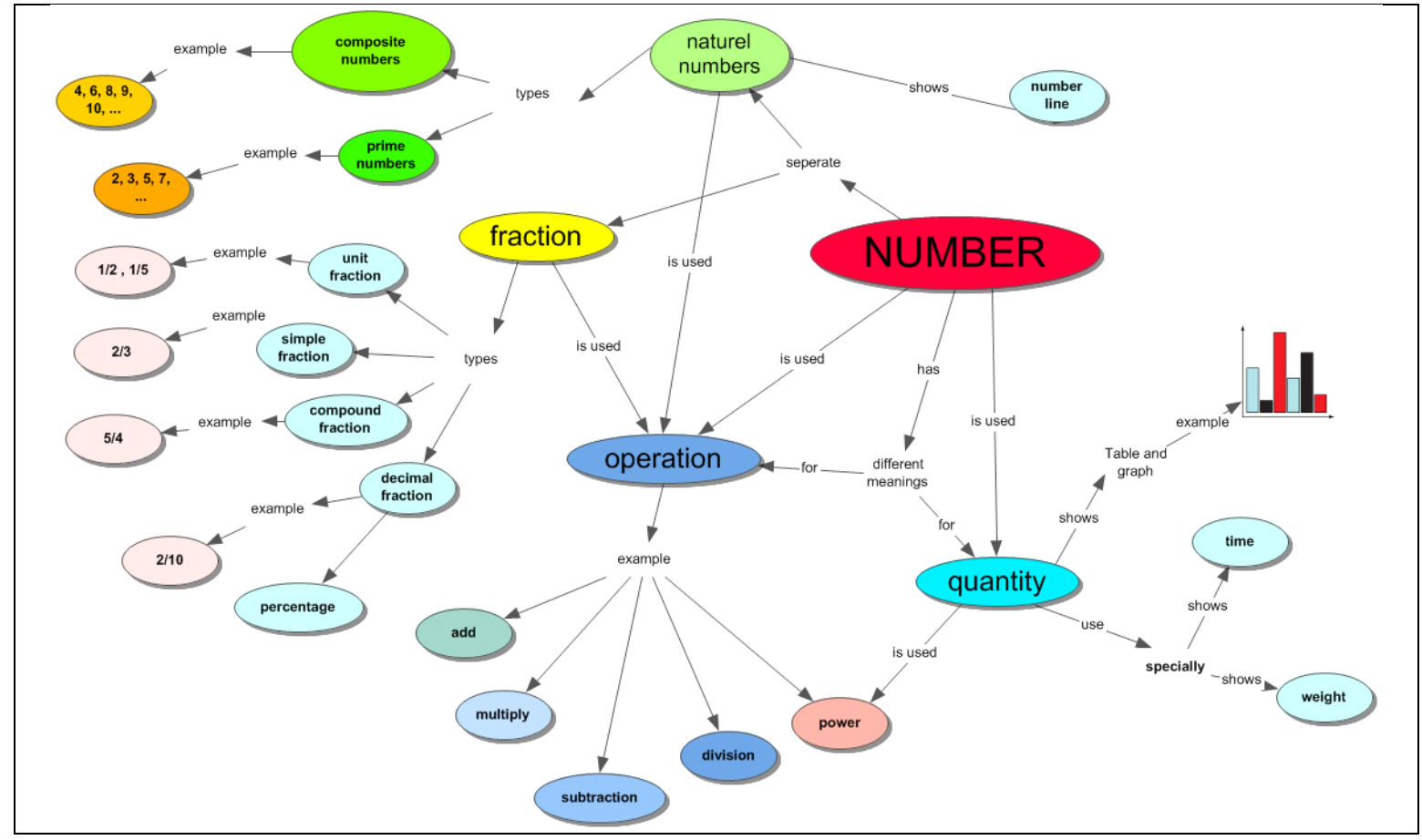

Figure 1

Furthermore, the concepts of point, line, curved line, broken line, line, segment and ray, which are the basic concepts of axiomatic structure of geometry, were left blank in the map, and the students were asked to fill in these blanks (Figure 2). 


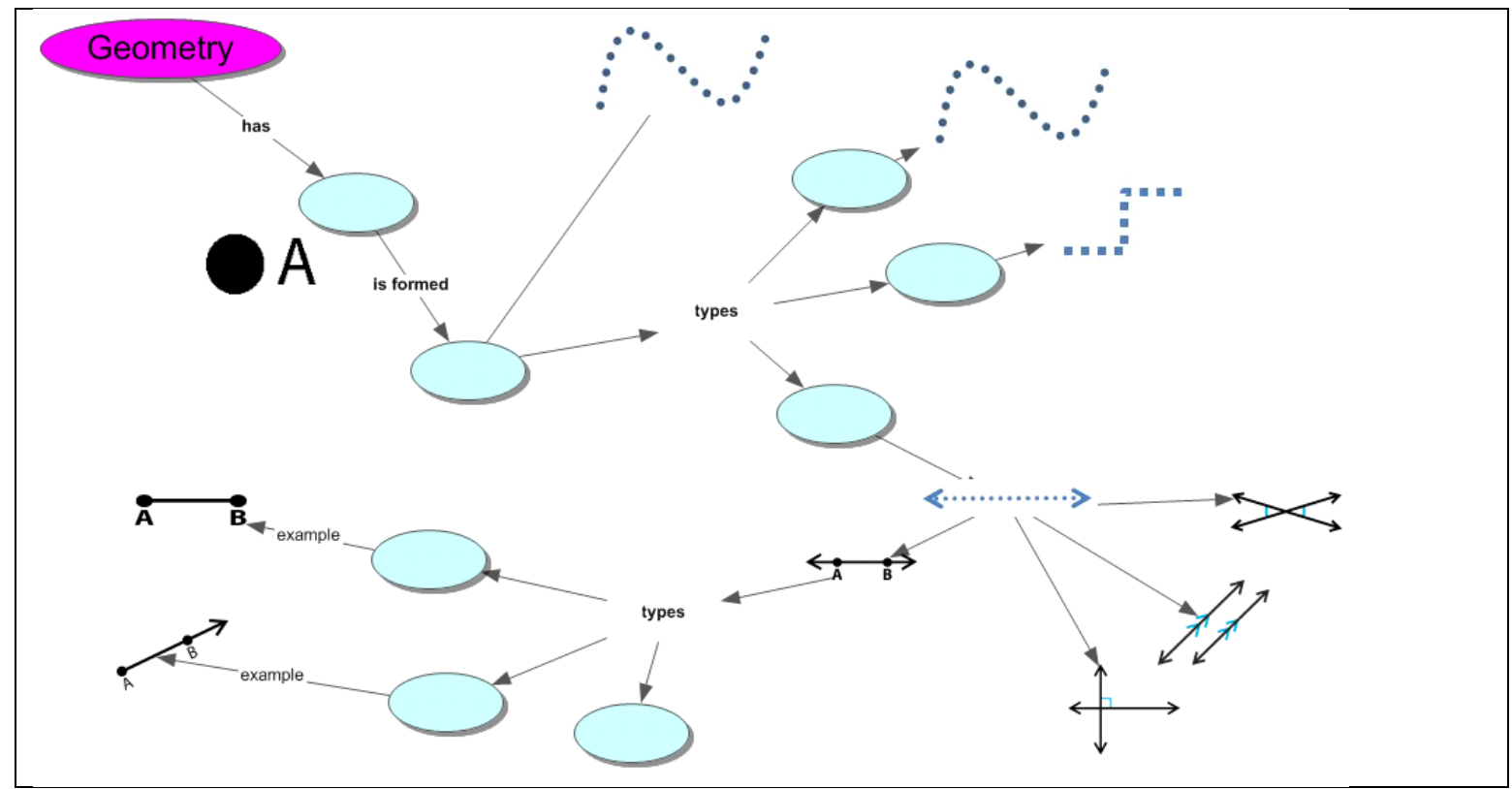

Figure 2

The subject of angles was prepared by the researchers on the computer using the concept map program Inspiration9 by taking opinions of experts and taught to the students in the experimental group in 4 lessons.

Likewise, the subject of angles is related to the subject area of measurement in mathematics. A teacher calls number $\alpha \in \square$ of an angle the measurement of that angle and knows that it is shown as $\alpha=m A O B$ or $\alpha=s A O B$, Axioms ( Angle measurement axioms) and "a real number of $r$ between 0 and 180 corresponds to every $A O B$ angle".

Students develop a concept image about angle measurement axiom by the activities in 4th grade of elementary school during which they measure angles using a protractor. The first image related to associating the numerical axis with a semi-circle is created while using a protractor. They develop knowledge related to types of angles over degrees. Therefore, teachers should utilize different means of activity while measuring angles (Figure 3) such as $0^{\circ}, 90^{\circ}, 180^{\circ}, 240^{\circ}$ and $360^{\circ}$ (Williams\&Shuard, 1991).

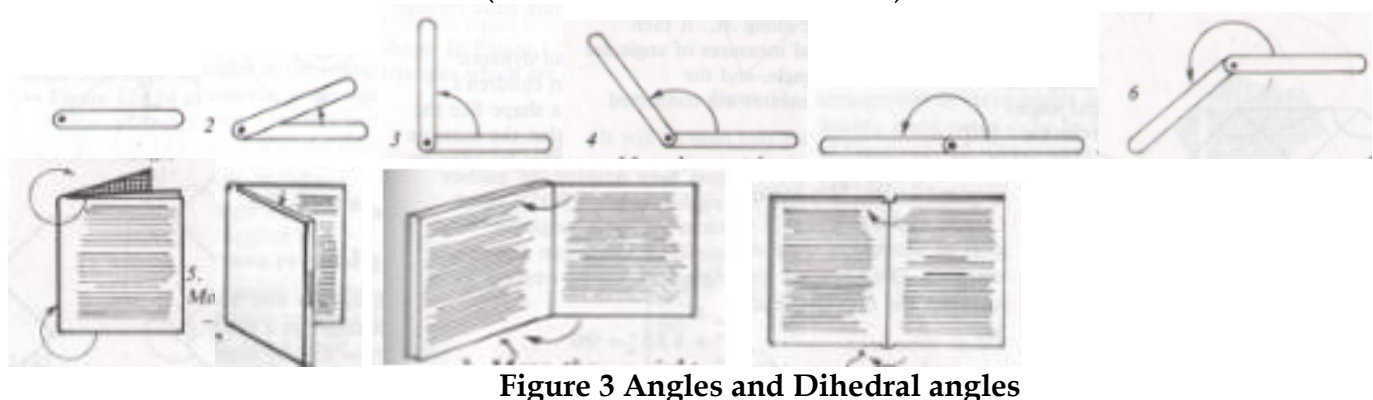

Performance test item analysis

While developing the measurement tool, a literature search was undertaken to reach available materials in the first stage. 5th grade math course books were supplied. Gains related to "angles" sub-learning area of "Geometry" learning area of Math Course were reviewed and 4-alternative multiple-choice test that includes 31 items was developed by researchers according to test development principles. The scoring was performed as follows: 1 point for a correct answer and 0 for a wrong answer. 
According to Item Analysis statistics conducted in SPSS 17 program, a 31-item test was developed for the research and applied to 315 students; as a result of statistics studies, items 3, 4, 5, 9, 12 and 25 were removed because they were below 0.3 (Çepni et al., 2008) and Corrected Item-Total Correlation was between 0.309 and 0.579 (Table 2).

Table 2

\begin{tabular}{cc}
\hline Cronbach's Alpha & N of Items \\
\hline, 873 & 25 \\
\hline
\end{tabular}

\section{Equivalence of the groups}

Relevant analysis was conducted to determine whether it is appropriate to first use parametric analysis methods to analyze data collected under the study as well as whether normality assumption was satisfied.

The groups were compared in terms of their attitude towards math before the implementation.

Table 3 Equivalence of the groups - pre-test Mathematics Attitude

\begin{tabular}{ccccc}
\hline Group & $\bar{X}$ & df & $\mathbf{t}$ & $\mathbf{P}$ \\
\hline Experiemental Group & 84.90 & \multirow{2}{*}{20} & -.479 & .637 \\
\hline Control Group & 83.43 & & &
\end{tabular}

In view of Table 3, this suggests that before the implementation, there is an equivalence $(\mathrm{t}(20)=-, 479 \mathrm{p}<, 637)$ between the student's mathematics attitude who will be taught angle concept using inspiration9 concept map (the experimental group) and the students who will be taught the same using traditional method (the control group).

\section{FINDINGS}

Pretest - posttest for angle concept conducted before teaching started and after it ended was compared between the groups.

Table 4 Comparision Mathematics Performance Post-test Score

\begin{tabular}{cccccc}
\hline Group & $\bar{X}$ & df & t & P \\
\hline Experiemental Group & 22.52 & \multirow{2}{*}{20} & \multirow{2}{*}{-1.820} & \multirow{2}{*}{001} \\
\hline Control Group & 15.76 & & & \\
\hline
\end{tabular}

Table 4 shows that in this study there is a significant difference $(t(20)=-1,820 p<, 001)$ between math performance scores of the students who were taught angle concept using inspiration9 concept map (the experimental group) and math performance scores of the group who were taught the same using traditional method (the control group) and this correlation is in favor of the experimental group. In this study, using concept map teaching method was effective on student performance.

Table 5 Comparision Experiemental Group Mathematics Pre - post test

\begin{tabular}{ccccc}
\hline Experiemental Group & $\bar{X}$ & df & t & $\mathbf{p}$ \\
\hline Pre- Test & 18.11 & \multirow{2}{*}{26} & \multirow{2}{*}{-6.481} & .000 \\
\hline Post-Test & 22.78 & & & \\
\hline
\end{tabular}

In view of Table 5 , it is clear that there is a significant difference $(t(26)=-6,481 p<, 000)$ between math performance pretest-posttest scores of the students in the experimental group (the group who used inspiration9 software). Teaching performed in this study using concept map has a positive effect on the students' math performance. 
Table 6 Comparision Control Group Mathematics Pre - post test

\begin{tabular}{cccccc}
\hline Control group & $\bar{X}$ & df & t & p \\
\hline Pre- Test & 15.29 & \multirow{2}{*}{20} & \multirow{2}{*}{1.644} & \multirow{2}{*}{116} \\
\hline Post-Test & 15.76 & & & \\
\hline
\end{tabular}

Table 6 shows that there is no significant difference $(\mathrm{t}(20)=-1,644 \mathrm{p}<, 116)$ between math performance pretest - posttest scores of the students in control group (traditional method). In this study, traditional teaching method wasn't effective on student performance.

Table 7 Comparision Mathematics Attitude Post-test Score

\begin{tabular}{ccccc}
\hline Grup & $\bar{X}$ & df & t & $\mathbf{p}$ \\
\hline Experiemental Group & 90.14 & \multirow{2}{*}{20} & \multirow{2}{*}{-2.398} & .026 \\
\hline Control Group & 79.86 & & & \\
\hline
\end{tabular}

It is clear from Table 7 that there is a significant difference $(t(20)=-2,398 p<, 026)$ between math performance scores of the students who were taught angle concept using inspiration9 concept map (the experimental group) and math performance scores of the group who were taught the same using traditional method (the control group) and this correlation is in favor of the experimental group. Teaching performed in this study using concept map has a positive effect on the students' attitudes toward math.

\section{CONCLUSION}

Burak (2010) noted that teaching 6th grade geometry subjects using concept map positively affects student performance. There are reports in the literature that teaching Calculus functions unit using concept maps improved performance, engagement with the course and motivation (Erdoğan, 2007), that teaching 9th Grade Functions chapter was effective in favor of the experimental group (Yağdıran, 2005), and that the group taught using computer-aided concept maps showed effective performance compared to the group taught using traditional method (Aykanat, 2005). This study is consistent with these research studies.

Children learn repeat strategies while going from kindergarten to fifth or sixth grade. They perform activities related to Grouping strategies, one of the strategies that ensure retaining the information in memory for a short time. So activities such as making a list related to angle concept, grouping angles according to their measurements, and seeing angles inside a group (Figure 4) are valuable. Such situations can be monitored in the activity of a student. 


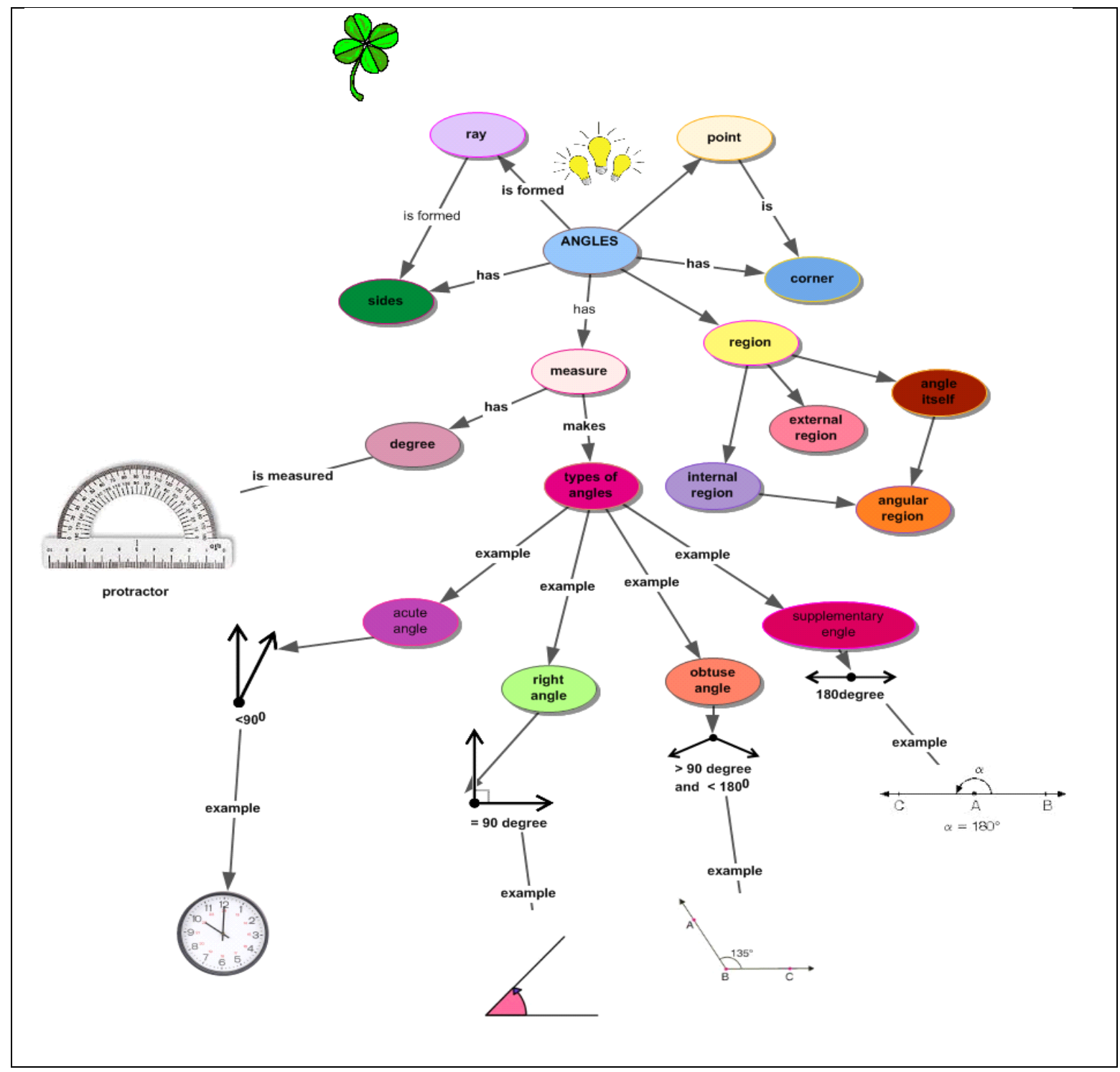

Figure 4 A $5^{\text {th }}$ Grade Students' work re-write english

Length and angle are the two basic concepts of geometry. Activities carried out with preschool, primary and secondary school students is critical in the acquisition of angle concept, which will be further associated with slope concept and trigonometry during high school years (Freudenthal 1983; Mitchelmore 1995, 2000; Mitchelmore,2002; White ve Mitchelmore, 2003).

For teachers who have limited time to learn, it can be seen as a waste of time to configure and assess concept maps (Uzuntiryaki, 1998). Teaching using concept maps may contribute to improvement of students' skills of seeing the concept in terms of representations, not within itself, thus, the activities not only enrich teaching but also lead to more in-depth thinking (Şekil 5 ). The student included the angle in a plane and showed it as an internal region. From there, it will be easier to move on to interior and exterior angle concept in polygons. Angle concept is expanded by associating it with polygons subject. 


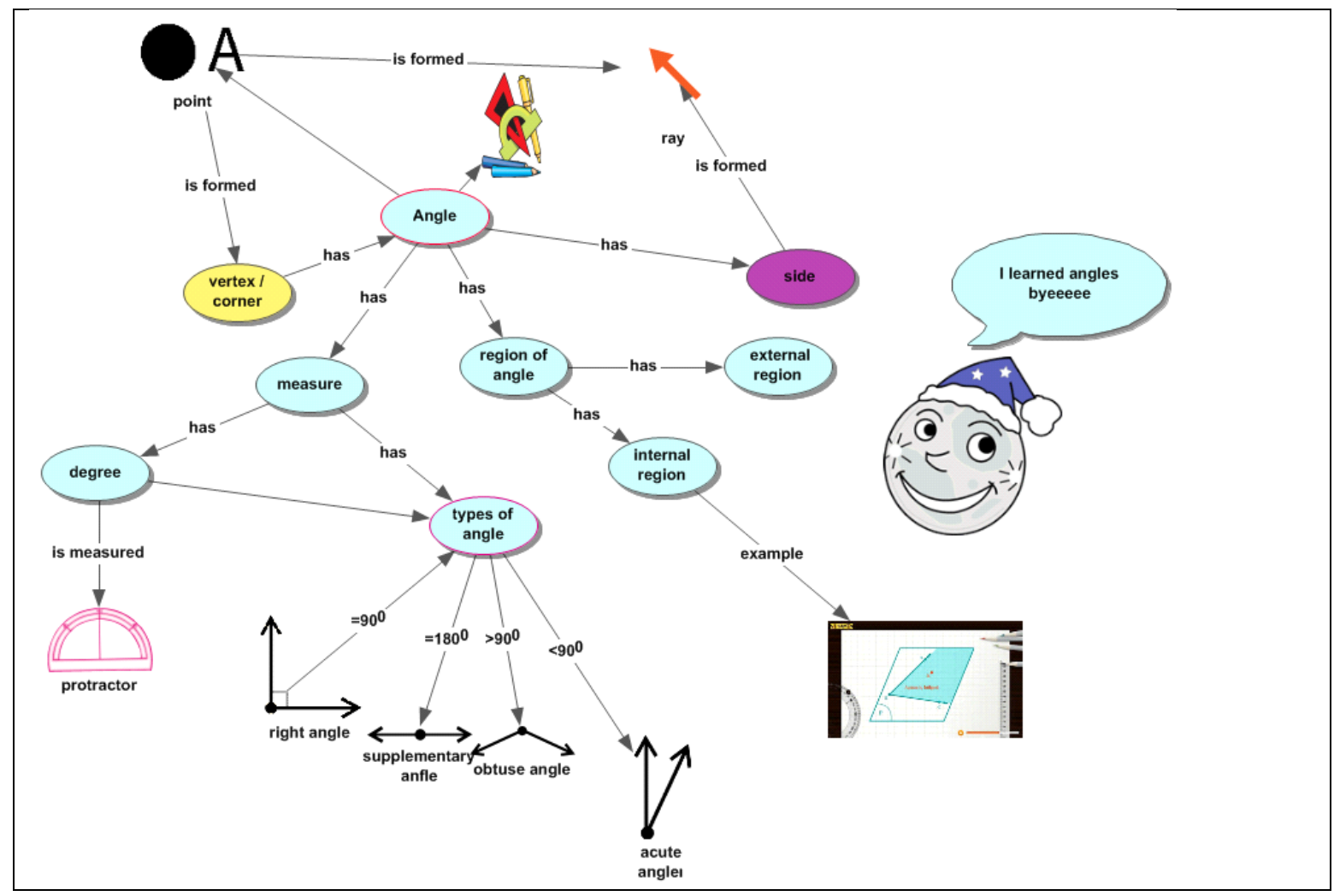

Figure 5 A $5^{\text {th }}$ Grade Students' work re-write English

Concept maps are constructed to show relationships between concepts. This activity doesn't involve sentences; it is built as a result of links. For example, in the case of sentence "angle is the combination of two rays sharing a common end-point", the concepts of "point" and "rays" are connected using a connecting line, and marked with the phrase "forms" and the connecting line connected to "angle" concept is also marked with the phrase "forms". In this way, links between concepts are visually apparent. In the study, a concept map made by a $5^{\text {th }}$ grade student (Figure 5) can be considered as a summary of his/her knowledge.

It can also contribute to rendering memory permanent by creating a concept list and sorting the concepts from the most general to the most specific with a specific hierarchy. It's like a table of contents and progresses in a hierarchical manner. It is a helpful tool for the development of metacognition strategies. Moreover, it is a work prepared by each student on his/her own. Concept maps with active learning strategy should induce different discoveries and pay attention that the connections between concepts are correct, whereas they should not be bound to a single evaluation. Concept maps are strictly connected to creative learning. They should be directed to revealing unnoticed relationships between the concepts. They should eliminate mediocrity. Many teachers and students expressed that by this method, they established links they haven't realized previously (Novak ve Gowin, 1993) and added that concept map is a creative activity and prevents extinction of creativity. During the study, a students asked "How do we call angles larger than 180 degrees?" It was stated that the angles between 180 degrees and 360 degrees are called reflexive angles. The map created by that student (Figure 6). In this respect, in-class activities are valuable. 


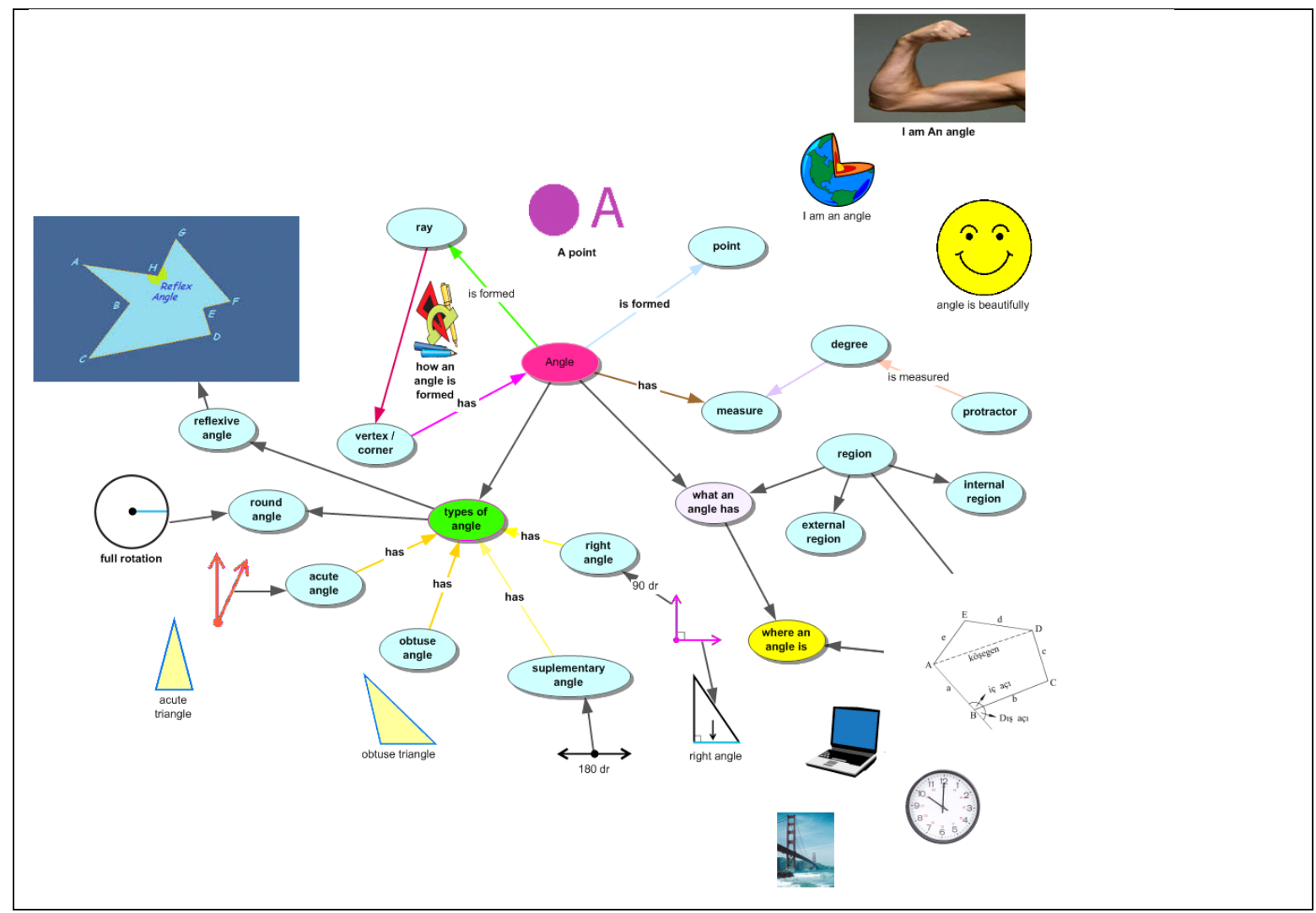

Figure 6 A $5^{\text {th }}$ Grade Students' work re-write english

Considering the properties of computers, many educators believe that the potential solution to limitations of concept maps created using pen and paper is computer technology (Tsai vd, 2001; Chang vd, 2001), which was also observed in this study. The students were also discovered to be enthusiastic during searches related to visuals. They require guidance from their teacher while searching for pictures related to concepts during this enthusiasm.

Computer-aided concept maps provide many advantages, including ease of adaptation, dynamic links, digital communication and digital recording. Computer-aided concept maps have the following benefits: 1) they can be saved, 2) they can be printed out and revised, where required, 3) very large maps can be constructed, 4) they can be combined, focused and 5) they encourage research (Rautuma, 2000). It is effective in monitoring improvement fro student portfolio (Anderson, Inman ve Ditson, 1999). In this respect, math teacher can support math with technology during his/her lesson.

Although concept maps allow acquisition of several pieces of propositional information related to the subject in the best manner, they cannot set forth adequate details about other elements of knowledge, such as images. Furthermore, concept maps are not very suitable for examining individual elements of knowledge (Atasoy, 2002). Complicated concept maps involve many correlations and lines so they may cause confusion in the minds of students (Uzuntiryaki, 1998). Age period of $5^{\text {th }}$ graders should be taken into consideration during the studies. 


\section{REFERENCES}

Aktaş, M., Güler, H.K, (2011), Sınıf Öğretmeni Adaylarının Dörtgenler Kavramına İlişkin Oluşturduklan Kavram Haritalarının Değerlendirilmesi, Gazi Eğitim Fakültesi Dergisi, Cilt 31, Sayı 2 s:605-618

Anderson Inman, L. ve Ditson, L., (1996), Computer- Based Cognitive Mapping: A Tool for Negotiating Meaning , Learning and Leading Technology, 26, 6-13.

Atasoy, B., 2002. Fen Öğrenimi ve Öğretimi, Asil Yayınları, 347s. Ankara.

Aykanat, F., 2005. Bilgisayar Destekli Kavram Haritaları Yöntemiyle Fen Öğretiminin Öğrenci Başarısına Etkisi, Kastamonu Eğitim Dergisi, Ekim 2005, cilt 13, no. 2, 391- 400.

Baki, A., (2008), Kuramdan Uygulamaya Matematik Ĕ̆itimi, Harf Yayıncılık, Ankara.

Baki, A., Şahin, S.M., (2004), Bilgisayar destekli kavram haritası yöntemiyle öğretmen adaylarının matematiksel öğrenmelerinin değerlendirilmesi, The Turkish Online Journal of Educational Technology - TOJET April 2004 ISSN: 1303-6521 volume 3 Issue 2 Article 14

Burak, H.S., (2010), İlköğretim 6. Sınıf matematik dersi geometri öğrenme alanında kavram haritası kullanmanın öğrencilerin başarıları ve bilgilerinin kalıcılığı üzerine etkisi, Gazi Ün. Eğitim Bilimleri Enstitüsü, Yayınlanmış Yüksek Lisans Tezi, Ankara.

Çepni, S., Bayrakçeken, S., Yılmaz, A., Yücel, C., Semerci, Ç., Köse, E., Sezgin, F., Demircioğlu, G. ve Gündoğdu, K. (2008). Ölçme ve Değerlendirme. Ankara: Pegem Akademi.

Chang, K., Sung, Y., Chen, S., 2001. Learning Thorough Computer-based Concept mapping With Scaffolding aid, Journal of Computer Assisted Learning 17, 21-33.

Çizenel, T., (1969), Geometri Lise 1 ders kitabı, Nurgök Matbaası

Clements, D. H., \& Battista, M. T. (1990). The effects of Logo on children's conceptualizations of angle and polygons. Journal for Research in Mathematics Education, 21(5), 356. ( http://www.jstor.org/stable/749394 )

Dede, Y. 2003. ARCS motivasyon modeli ve öğe gösterim teorisine (Component display theory) dayalı yaklaşımın öğrencilerin değişken kavramını öğrenme düzeylerine ve motivasyonlarına etkisi. Doktora tezi. Gazi Üniversitesi Eğitim bilimleri Enstitüsü, Ankara.

Erdem, A., (1968), Trigonometri ve çözümlü problemleri, Kutulmuş Matbaası, Sultanahmet, İstanbul

Erdoğan, A., (2007). Kavram Haritalarının Calculus Yönteminde Kullanılması. Selçuk Üniversitesi Fen bilimleri Enstitüsü Doktora Tezi , 79 s, Konya.

Freudenthal, H. (1983). Didactical phenomenology of mathematical structures. Dordrecht, The Netherlands: Reidel.

Fuys, D., Geddes, D., \& Tischler, R. (1988). The van Hiele model of thinking in geometry among adolescents. Journal for Research in Mathematics Edcation Monograph Series, Number 3. Reston, VA: National Council of Teachers of Mathematics.

Gökmen, İ., (1968), Düzlemde Geometri, Berksoy Matbaası, İstanbul.

Güçlüer, E. (2006). İlköğretim Fen Bilgisi Eğitiminde Kavram Haritaları İle Verilen Bilişsel Desteğin Başarıya Hatırda Tutmaya Ve Fen Bilgisi Dersine İlişkin Tutuma Etkisi. Yüksek Lisans Tezi. Dokuz Eylül Üni., Eğitim Bilimleri Enstitüsü, İzmir.

Harnisch, D.L, Sato, T., Zheng, P., Yamagi, S.,\& Connell,M., (1994), Concept Mapping approach and its applications in instruction and assesment. Paper presented at annual meeting of the American Educational Research Association, New Orleans, LA.

Henderson, L., (1994). Interactive Multimedia, Concept Mapping and Cultural Context, Eric Database, No: ED388255. 
Cumhuriyet International Journal of Education-CIJE

e-ISSN: 2147-1606

Vol 3 (2), 2014, $70-84$

Hiebert, J. and Carpetner, T., (1992), 'Learning and teaching with understanding,' in D. Grouws (ed.), Handbook of Research on Mathematics Teaching and Learning, MacMillan, New York, pp. 65-97.

Hiebert, J. and Lefevre, P., (1986), 'Conceptual and procedural knowledge in mathematics: An introductory analysis', in J. Hiebert (ed.), Conceptual and Procedural Knowledge: The Case of Mathematics, Lawrence Erlbaum, Hillsdale, New Jersey, pp. 1-27.

Jones, B.F., Palinscar, A.S., Ogle, D.S., \& Carr, E.G. DH (Eds.) (1987). Strategic teaching and learning: Cognitive instruction in the content areas. Elmhurst, IL: North Central Regional Laboratory and the Association for Supervision and Curriculum Development.

Kabaca, Y., M. (2003). Kavram Haritalarının Matematik Öğretiminde Ölçme ve Değerlendirme Aracı Olarak Kullanımının İncelenmesi. Yüksek Lisans Tezi, Marmara Üniversitesi, Eğitim Bilimleri Enstitüsü, İstanbul.

Kaptan, F. (1998). Fen Öğretiminde Kavram Haritası Yönteminin Kullanılması. Hacettepe Eğitim Fakültesi Dergisi, 14, s. 95-99.

Keiser, J. M. (2004). Struggles with developing the concept of angle: Comparing sixth-grade students' discourse to the history of the angle concept. Mathematical Thinking and Learning An International Journal, 6(3), 285.

Mitchelmore, M. C. (1998). Young students' concepts of turning and angle. Cognition and Instruction, 16(3), 265.

Mitchelmore, M. C., \& White, P. (1995). Development of the angle concept by abstraction from situated knowledge. Paper presented at the meeting of the American Educational Research Association, San Francisco.

Mitchelmore, M. C., \& White, P. (2000). Development of angle concepts by progressive abstraction and generalisation. Educational Studies in Mathematics, 41(3), 209.

Mitchelmore, M. C., \& White, P. (2003). Count Me In Too and the Basic Skills Test in New South Wales. In Bragg, L., Campbell, C., Herbert, G., \& Mousley, J. (Eds.), Mathematics Education Research: Innovation, Networking, Opportunity (Proceedings of the 26th annual conference of the Mathematics Education Research Group of Australasia, Geelong, pp. 515-522). Sydney: MERGA.

Noss, R. (1987). Children's learning of geometrical concepts through Logo. Journal for Research in Mathematics Education, 18, 343-362.

Novak, J. D., (1990). Concept Mapping: A Useful Tool for Science Education. Journal of Research in Science Teaching. 27 (4), 937-949.

Novak, J. D., Gowin, D. B., (1984). Learning How to Learn. Newyork, Cambridge University Press.

Novak, J.D. , Gowin, D.B. Ve Johansen, G.T. (1983). The Use of Concept Mapping and Knowledge Vee Mapping With Junior High School Science Students, Science Education, 67(5), p. 625-645.

Novak, J.D. Ve Wandersee, J.H. (1990). Perspectives on Concept Mapping, Journal of Research in Science Teaching, 27(10).

Özdemir, A. (2009). İlköğretim 6. Sınıf Matematik Dersi "Kesirler" Konusunun Öğretiminde Kavram Haritası Kullanımının Öğrenci Başarısına Etkisi. Yüksek Lisans Tezi. Gazi Üniversitesi, Eğitim Bilimleri Enstitüsü, İlköğretim Anabilim Dalı, İlköğretim Matematik Öğretmenliği Bilim Dalı. Ankara.

Piaget, J., \& Inhelder, B. (1956). The child's conception of space. London: Routledge \& Kegan Paul.

Prescott, A., Mitchelmore, M., \& White, P. (2002). Student difficulties in abstracting angle concepts from physical activities with concrete materials. Paper presented at the The 25th Annual Conference of the Mathematics Education Research Group of Australia 
Incorporated, Auckland, New Zealand.Reyes, L. H. (1984). Affective variables and mathematics education. The Elementary School Journal. Vol. 84, No. 3

Şahin, B. (2003). Matematik Dersinde Kavram Haritası yöntemini Kullanarak Öğrenci Başarısının Değerlendirilmesine İlişkin Bir Araştırma. Doktora Tezi. Hacettepe Üniversitesi, Sosyal Bilimler Enstitüsü. Ankara.

Sinclair, H., (1991). Learning: The interactive recreation of knowledge. In L. P. Steffe\&T.Wood (Eds.), Transforming children's mathematics education (pp. 19-29). Hillsdale, NJ: Lawrence Erlbaum Associates, Inc.

Tall, D. O., \& Vinner, S. (1981). Concept image and concept definition in mathematics, with particular reference to limits and continuity. Educational Studies in Mathematics, 12, 151-169.

Tsai, C., Lin,S. ve Yuan, S., 2001. Students'use of Web-Based Concept MapTesting and Strategies for Learning, Journal of Computer Assisted Learning, 17. 72-84.

Uzuntiryaki, U. (1998). The Effects of Conceptual Change Text Accompanied with Concept Mapping on Understanding of Solution. Orta Doğu Teknik Üniversitesi, Yüksek Lisans Tezi, Ankara.

White, P., \& Mitchelmore, M. (2003). Teaching angles by abstraction from physical activities with concrete materials. In N. Pateman, B. J. Dougherty, \& J. Zillox (Eds.), Proceedings of the 27th PME International Conference, 4, 403-41.

Williams, E.\& Shuard, H., (1991), "Primary Mathematics Today", 4th Edition, towards 21 st century, Longman

Yağdıran, E., 2005. Ortaöğretim 9. Sınıf Fonksiyonlar Ünitesinin Çalışma Yaprakları, Vee Diyagramları Ve Kavram Haritası Kullanılarak Öğretilmesi. Balıkesir Üniversitesi Fen bilimleri Enstitüsü Yüksek Lisans Tezi, 162s. Balıkesir. 